\title{
Corrosion and hydrogenation of steels in solutions of mineral acids containing iron(III) salts
}

\author{
Ya.G. Avdeev, ${ }^{1}{ }^{*}$ L.V. Frolova, ${ }^{1}$ A.V. Panova, ${ }^{1}$ K.L. Anfilov ${ }^{2}$ \\ and Yu.I. Kuznetsov ${ }^{1}$ \\ ${ }^{1}$ A.N. Frumkin Institute of Physical Chemistry and Electrochemistry, Russian Academy of \\ Sciences, Leninskii pr. 31, Moscow, 119071 Russian Federation \\ ${ }^{2}$ Federal State Budgetary Educational Institution of Higher Education "Bauman Moscow \\ State Technical University” (Kaluga Branch), Bazhenov str. 2, Kaluga, 248000 Russian \\ Federation \\ *E-mail: avdeevavdeev@mail.ru
}

\begin{abstract}
The pickling and washing processing solutions of sulfuric acid accumulate $\mathrm{Fe}$ (III) cations in the course of operation, mainly as a result of the dissolution of scale and mineral deposits. $\mathrm{Fe}(\mathrm{III})$ cations significantly worsen the inhibitory protection of steels in contact with the acid. The corrosion and hydrogenation of low-carbon steel 08PS and high-strength steel 70C2XA in $2 \mathrm{M} \mathrm{H}_{2} \mathrm{SO}_{4}, 2 \mathrm{M} \mathrm{H}_{2} \mathrm{SO}_{4}+\mathrm{H}_{3} \mathrm{PO}_{4}$ and $2 \mathrm{M} \mathrm{H}_{3} \mathrm{PO}_{4}$ solutions containing $\mathrm{Fe}$ (III) salts were studied within the temperature range from 25 to $60^{\circ} \mathrm{C}$. The hydrogenation of steels in these media depends on the chemical composition of steel, anionic composition of the corrosive media, and concentration of Fe(III) salts in them, temperature, and the presence of a corrosion inhibitor in the medium. It was established that in the case of a potential danger of accumulation of $\mathrm{Fe}$ (III) salts in inhibited pickling sulfuric acid solutions that substantially increases their corrosiveness to steels, their replacement with $\mathrm{H}_{2} \mathrm{SO}_{4}+\mathrm{H}_{3} \mathrm{PO}_{4}$ mixtures inhibited by a formulation of IFKhAN-92, KSCN, and urotropine (in 9:1:400 molar ratio) is a promising step. Unlike a similar solution of $\mathrm{H}_{2} \mathrm{SO}_{4}$, the corrosion losses and hydrogenation of low-carbon and high-strength steels are insignificant even in the case of substantial accumulation of $\mathrm{Fe}(\mathrm{III})$ cations (up to $0.1 \mathrm{M}$ ).
\end{abstract}

Keywords: acid corrosion, corrosion inhibitors, triazoles, low-carbon steel, hydrogenation of steel, sulfuric acid, phosphoric acid, iron(III) sulfate, iron(III) phosphate.

Received: January 21, 2020. Published: February 21, 2020

doi: $\underline{10.17675 / 2305-6894-2020-9-1-21}$

Inhibited solutions of $\mathrm{H}_{2} \mathrm{SO}_{4}$ have broad applications for the removal of heating furnace cinder and washing of internal surfaces of steel equipment from mineral deposits. In the course of operation, these process solutions accumulate Fe(III) cations, mainly as a result of the dissolution of scale and mineral deposits. Fe(III) cations significantly worsen the inhibitory protection of metal in contact with the acid [1]. The solution to this problem might be to replace individual sulfuric acid solutions with their mixtures with $\mathrm{H}_{3} \mathrm{PO}_{4}$. The use of two- or three-component formulations based on a triazole derivative - IFKhAN-92 
makes it possible to provide inhibitory protection of low-carbon steel in these media even if there is a significant amount of accumulated Fe(III) salts (up to $0.1 \mathrm{M}$ ) [2-4]. In this case, the composition of IFKhAN-92, KSCN, and urotropine with a 9:1:400 molar ratio is the most promising. This composition can be used both in mixtures of $\mathrm{H}_{2} \mathrm{SO}_{4}$ with $\mathrm{H}_{3} \mathrm{PO}_{4}$ and $\mathrm{HCl}$ with $\mathrm{H}_{3} \mathrm{PO}_{4}$ where $\mathrm{Fe}(\mathrm{III})$ cations are accumulated in these environments [4].

The corrosion of steel in an aqueous acid environment is followed by release of hydrogen, which often results in the hydrogenation of the metal that can worsen its mechanical properties $[5,6]$. The regularities of hydrogen cathodic release, its penetration into iron in an acid environment, and the effect on the kinetics of its anodic dissolution were analyzed in detail in reviews [7-9].

It is relevant to identify the peculiarities of the effect of organic inhibitors for acid corrosion on the hydrogenation of steels. Special attention is paid to the study of wellknown inhibitors of the quaternary ammonium salt class (QAS). Marshakov et al. $[10,11]$ revealed that unlike benzonitrile and dibutyl sulfoxide, tetrabutylammonium sulfate and tetraethylammonium bromide did not alter the mechanism of cathodic release of hydrogen in acid sulfate solutions but significantly inhibited its penetration into iron. Later, Tsygankova et al. also observed a decrease in hydrogen diffusion into steel due to Catamin $A B$ in acid sulfate and chloride solutions [12-14]. In our works [15, 16], it was shown that the IFKhAN-92 inhibitor and formulations on its basis significantly suppressed not only the corrosion of chromium-nickel steels in acid solutions but also their hydrogenation. Despite the practical importance of the issue and comprehensive study of the regularities and mechanism of steel hydrogenation in acid environments, there are no data in available literature on the effect of Fe(III) salts on steel hydrogenation in acidic solutions, both in the presence and absence of corrosion inhibitors.

Based on the above, it seems appropriate to study the impact of the presence of $\mathrm{Fe}$ (III) salts in solutions of $\mathrm{H}_{2} \mathrm{SO}_{4}$ and its mixtures with $\mathrm{H}_{3} \mathrm{PO}_{4}$ on the corrosion and hydrogenation of steels in these media. The IFKhAN-92+KSCN+urotropine formulation was examined as an inhibitor of steel corrosion in these media since it ensures their protection in acids containing $\mathrm{Fe}(\mathrm{III})$ cations.

\section{Experimental}

The corrosion rate of low-carbon steel 08PS (composition, mass \%: $\mathrm{C}-0.08 ; \mathrm{Mn}-0.5$; $\mathrm{Si}-0.11 ; \mathrm{P}-0.035 ; \mathrm{S}-0.04 ; \mathrm{Cr}-0.1 ; \mathrm{Ni}-0.25 ; \mathrm{Cu}-0.25 ; \mathrm{As}-0.08)$ in $2 \mathrm{M} \mathrm{H}_{2} \mathrm{SO}_{4}$, $2 \mathrm{M} \mathrm{H}_{2} \mathrm{SO}_{4}+\mathrm{H}_{3} \mathrm{PO}_{4}$, and $2 \mathrm{M} \mathrm{H}_{3} \mathrm{PO}_{4}$ was determined from the mass loss of strip samples with dimensions of $50 \mathrm{~mm} \times 20 \mathrm{~mm}$ (no less than 3 samples per point) using $50 \mathrm{~mL}$ of the acid solution per specimen. The exposure time was $2 \mathrm{~h}$. Before the experiment, the samples were cleaned on an abrasive disc (ISO 9001, grain class 60) and degreased with acetone.

High strength 70C2XA steel (composition, mass \%: C - 0.7; Mn - 0.52; Si - 1.52; $\mathrm{Cr}-0.3$ ) was selected as the object of this study due to its liability to hydrogenation and the feasibility of measuring the plastic properties of steel. The corrosion rate of 70C2XA 
steel in the environment studied was determined from the mass losses of specimens (no less than 3 samples per point) with dimensions of $110 \mathrm{~mm} \times 15 \mathrm{~mm} \times 0.5 \mathrm{~mm}$ using $50 \mathrm{~mL}$ of the acid solution per sample. The duration of the tests was $2 \mathrm{~h}$. Before a test, the samples were cleaned from the preservative compound, their surface was activated with a mixture of concentrated $\mathrm{HCl}(10 \%)$ with acetone. After that, they were wiped dry with a cotton cloth.

The solutions were prepared using $\mathrm{H}_{2} \mathrm{SO}_{4}$ and $\mathrm{H}_{3} \mathrm{PO}_{4}$ acids of chemically pure grade and distilled water. Acid solutions containing Fe(III) salts were prepared by reacting $\mathrm{Fe}(\mathrm{OH})_{3}$, which was precipitated by $\mathrm{NaOH}$ (chemically pure grade) from a $\mathrm{FeCl}_{3}$ solution, with an excess of the corresponding acid. $\mathrm{FeCl}_{3} \cdot 6 \mathrm{H}_{2} \mathrm{O}$ (pure) was used to prepare the solution of Fe(III) chloride.

The degree of hydrogenation of 70C2XA and 08PS steels was determined using the vacuum extraction method. After the corrosion test, a sample was placed into a vessel from which air was evacuated to a residual pressure of $1.33 \cdot 10^{-4} \mathrm{~Pa}$, and then it was heated to $500^{\circ} \mathrm{C}$. The amount of hydrogen released upon heating the sample was estimated by changes in 10 min in the total pressure $\left(P_{\text {total }}\right)$ measured by a McLeod manometer at a constant volume of the evacuated part of the system. The pressure of released hydrogen $\left(P_{\mathrm{H}_{2}}\right)$ was calculated by changes in $P_{\text {total }}$ using the formula:

$$
P_{\mathrm{H}_{2}}=P_{\text {total }}-P_{\text {correct. }}
$$

where $P_{\text {correct. }}$ is the blank correction. The volume concentration of hydrogen in steel $(\mathrm{mL} / 100 \mathrm{~g}$ of steel) was calculated by the formula:

$$
V_{\mathrm{H}_{2}}=\frac{100 K P_{\mathrm{H}_{2}}}{M}
$$

where $K$ is a constant related to the volume of the analytical part of the setup; $M$ is the mass of the steel sample, $\mathrm{g}$. The data on the metal hydrogenation were adjusted for metallurgical hydrogen, the concentration of which amounted to 0.03 and $0.04 \mathrm{~mL} / 100 \mathrm{~g}$ for steel 08PS and 70C2XA steel, respectively.

An NG-1-3M device was employed to evaluate plastic behavior of 70C2XA steel based the number of bends of strip samples until breakdown when they are in the initial state $\left(N_{0}\right)$ and after they were exposed in an acid solution $(N)$. The plasticity of steel was calculated by the formula:

$$
p=\frac{N}{N_{0}} \cdot 100 \%
$$

For the studied sample of 70C2XA steel, the average value of $N_{0}$ is 87 . 


\section{Results and discussion}

The corrosion of low-carbon steel 08PS in $2 \mathrm{M} \mathrm{H}_{2} \mathrm{SO}_{4}$ solution accelerates with an increase in $t$ (Tables 1 and 2). In this case, steel hydrogenation increases with an increase in temperature from 25 to $60^{\circ} \mathrm{C}$; a further $t$ growth decreases the metal hydrogenation. The presence of $\mathrm{Fe}_{2}\left(\mathrm{SO}_{4}\right)_{3}$ in the acid accelerated the corrosion within the entire temperature range studied. The values of $k$ became higher as the amount of $\mathrm{Fe}$ (III) in the solution increased. At $t=25^{\circ} \mathrm{C}$, the presence of $\mathrm{Fe}_{2}\left(\mathrm{SO}_{4}\right)_{3}$ in the solution enhanced the metal hydrogenation, while at higher temperatures, it did the opposite, i.e., decreased hydrogenation.

Table 1. Corrosion rates $\left(k, \mathrm{~g} /\left(\mathrm{m}^{2} \cdot \mathrm{h}\right)\right)$ and hydrogenation $\left(V_{\mathrm{H}_{2}}, \mathrm{~mL} / 100 \mathrm{~g}\right)$ of $08 \mathrm{PS}$ steel in $2 \mathrm{M} \mathrm{H}_{2} \mathrm{SO}_{4}$.

\begin{tabular}{ccccccc}
\hline & \multicolumn{2}{c}{$\mathbf{2 5}^{\circ} \mathbf{C}$} & \multicolumn{2}{c}{$\mathbf{4 0}^{\circ} \mathbf{C}$} & \multicolumn{2}{c}{$\mathbf{8 0}^{\circ} \mathbf{C}$} \\
\cline { 2 - 7 } $\mathbf{C}(\mathbf{F e}(\mathbf{I I I})), \mathbf{M}$ & $\boldsymbol{k}$ & $\boldsymbol{V}_{\mathbf{H}_{2}}$ & $\boldsymbol{k}$ & $\boldsymbol{V}_{\mathbf{H}_{2}}$ & $\boldsymbol{k}$ & $\boldsymbol{V}_{\mathbf{H}_{2}}$ \\
\hline 0 & 9.8 & 0.13 & 51 & 0.34 & 680 & 0.21 \\
0.005 & 10 & 0.13 & 51 & 0.34 & 681 & m.h.* \\
0.01 & 11 & 0.13 & 54 & 0.34 & 690 & m.h. \\
0.02 & 12 & 0.13 & 56 & 0.13 & 699 & m.h. \\
0.05 & 15 & 0.16 & 59 & 0.18 & 710 & m.h. \\
0.1 & 18 & 0.23 & 61 & 0.20 & 750 & m.h. \\
\hline
\end{tabular}

*metallurgical hydrogen $(0.04 \mathrm{~mL} / 100 \mathrm{~g})$.

Table 2. Corrosion rate $\left(k, \mathrm{~g} /\left(\mathrm{m}^{2} \cdot \mathrm{h}\right)\right)$ and hydrogenation $\left(V_{\mathrm{H}_{2}}, \mathrm{~mL} / 100 \mathrm{~g}\right)$ of 08PS steel in acid solutions at $60^{\circ} \mathrm{C}$.

\begin{tabular}{ccccccc}
\hline \multirow{2}{*}{$\begin{array}{c}\boldsymbol{C}(\mathrm{Fe}(\mathrm{III})), \\
\mathbf{M}\end{array}$} & \multicolumn{2}{c}{$\mathbf{2} \mathbf{M ~ H}_{\mathbf{2}} \mathbf{S O}_{\mathbf{4}}$} & $\mathbf{1} \mathbf{M ~ H}_{\mathbf{2}} \mathbf{S O}_{\mathbf{4}}+\mathbf{1 . 0} \mathbf{M ~ H}_{\mathbf{3}} \mathbf{P O}_{\mathbf{4}}$ & \multicolumn{2}{c}{$\mathbf{2} \mathbf{M ~ H}_{\mathbf{3}} \mathbf{P O}_{\mathbf{4}}$} \\
\cline { 2 - 7 } & $\boldsymbol{k}$ & $\boldsymbol{V}_{\mathbf{H}_{2}}$ & $\boldsymbol{k}$ & $\boldsymbol{V}_{\mathbf{H}_{2}}$ & $\boldsymbol{k}$ & $\boldsymbol{V}_{\mathbf{H}_{2}}$ \\
\hline 0 & 172 & 0.54 & 143 & 0.06 & 105 & m.h.* \\
0.005 & 172 & 0.13 & 139 & 0.06 & 90 & m.h. \\
0.01 & 181 & 0.13 & 138 & 0.06 & 87 & m.h. \\
0.02 & 183 & 0.2 & 136 & 0.06 & 71 & m.h. \\
0.05 & 195 & 0.18 & 131 & 0.06 & 71 & m.h. \\
0.1 & 204 & 0.11 & 131 & 0.06 & 71 & 0.03 \\
\hline
\end{tabular}




\begin{tabular}{|c|c|c|c|c|c|c|}
\hline \multirow{2}{*}{$\begin{array}{c}C(\mathrm{Fe}(\mathrm{III})), \\
\mathbf{M}\end{array}$} & \multicolumn{2}{|c|}{$2 \mathrm{M} \mathrm{H}_{2} \mathrm{SO}_{4}$} & \multicolumn{2}{|c|}{$1 \mathrm{M} \mathrm{H}_{2} \mathrm{SO}_{4}+1.0 \mathrm{M} \mathrm{H}_{3} \mathrm{PO}_{4}$} & \multicolumn{2}{|c|}{$2 \mathrm{M} \mathrm{H}_{3} \mathrm{PO}_{4}$} \\
\hline & $\boldsymbol{k}$ & $V_{\mathrm{H}_{2}}$ & $\boldsymbol{k}$ & $V_{\mathbf{H}_{2}}$ & $\boldsymbol{k}$ & $\boldsymbol{V}_{\mathrm{H}_{2}}$ \\
\hline \multicolumn{7}{|c|}{$4.5 \mathrm{mM}$ IFKhAN-92+0.5 mM KCNS+200 mM urotropine } \\
\hline 0 & 0.68 & 0.35 & 0.48 & 0.40 & 0.33 & 0.05 \\
\hline 0.005 & 1.1 & 0.34 & 0.59 & 0.32 & 0.42 & 0.06 \\
\hline 0.01 & 1.3 & 0.28 & 0.67 & 0.32 & 0.49 & 0.08 \\
\hline 0.02 & 2.6 & 0.18 & 0.68 & 0.27 & 0.58 & 0.09 \\
\hline 0.05 & 5.5 & 0.08 & 0.73 & 0.27 & 1.0 & 0.09 \\
\hline 0.1 & 9.5 & m.h. & 1.2 & 0.25 & 1.3 & 0.09 \\
\hline
\end{tabular}

*metallurgical hydrogen $(0.04 \mathrm{~mL} / 100 \mathrm{~g})$.

In general, low-carbon steel is not prone to hydrogenation in $2 \mathrm{M} \mathrm{H}_{2} \mathrm{SO}_{4}$, and the maximum content of hydrogen in the metal sample is observed at $t=60^{\circ} \mathrm{C}$ and amounts to $0.54 \mathrm{~mL} / 100 \mathrm{~g}$. The presence of $\mathrm{Fe}_{2}\left(\mathrm{SO}_{4}\right)_{3}$ in the solution does not considerably affect the hydrogenation of metal whereas corrosion losses grow significantly. Studies for high strength steel 70C2XA may provide more information on the impact of $\mathrm{Fe}$ (III) cations on the corrosion and hydrogenation of steel. This steel is also an interesting object of study because it allows one to evaluate mechanical properties, along with the metal corrosion losses and hydrogenation. The deterioration of mechanical properties of high strength steels is believed to be predominantly caused by their hydrogenation. Surely, there must be a correlation between the hydrogenation of high strength steel and a loss in its plasticity. This correlation is often used for indirect determination of steel hydrogenation when it is identified through losses in mechanical properties [3].

The corrosion losses of 70C2XA steel are significantly higher than those of lowcarbon steel, and this steel is also more susceptible to hydrogenation (Figure 1). The corrosion of $70 \mathrm{C} 2 \mathrm{XA}$ steel in $2 \mathrm{M} \mathrm{H}_{2} \mathrm{SO}_{4}$ accelerates with temperature $t$, but only the addition of $0.1 \mathrm{M} \mathrm{Fe}$ (III) causes a marked increase in the $k$ value for steel $\left(t=25\right.$ and $40^{\circ} \mathrm{C}$ ). At $25^{\circ} \mathrm{C}$, the addition of a $\mathrm{Fe}(\mathrm{III})$ salt reduces metal hydrogenation (down to $50 \%$ ). The increase in $t$ slightly affects metal hydrogenation but significantly accelerates corrosion. In contrast, $\mathrm{Fe}$ (III) increases hydrogenation under these conditions: up to 37 and $68 \%$ at $t=40$ and $60^{\circ} \mathrm{C}$, respectively. We attribute the absence of the expected noticeable gain in steel hydrogenation with temperature to the high corrosion of steel when its hydrogen-charged surface layer dissolves quickly, and hydrogen absorbed by the metal does not have time to penetrate into its bulk. 


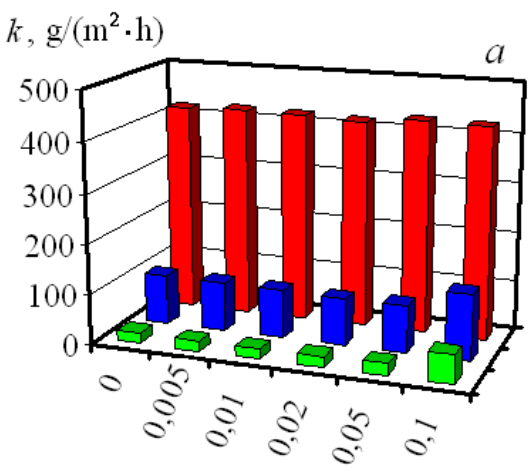

$C(\mathrm{Fe}($ III) $), \mathrm{mol} / \mathrm{l}$

$k, \mathrm{~g} /\left(\mathrm{m}^{2} \cdot \mathrm{h}\right)$

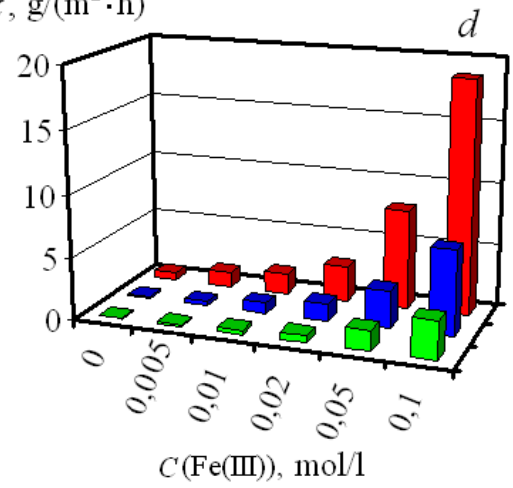

$\square-25^{\circ} \mathrm{C} \quad \square-40^{\circ} \mathrm{C} \quad \square-60^{\circ} \mathrm{C}$

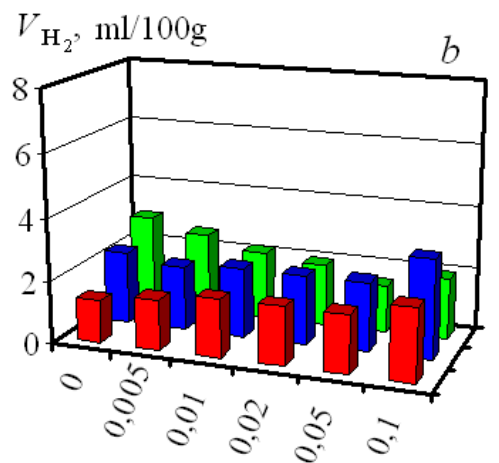

$\mathrm{C}(\mathrm{Fe}(\mathrm{III})), \mathrm{mol} / 1$

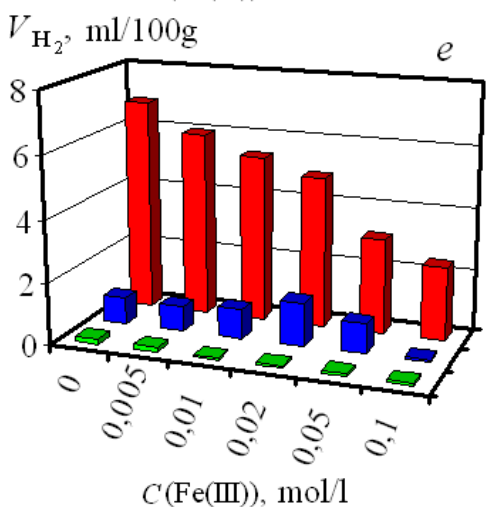

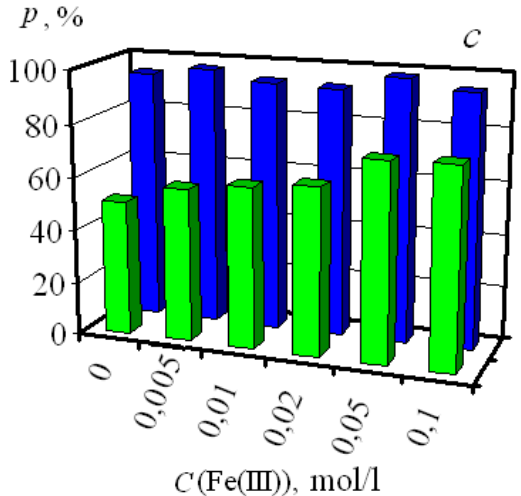

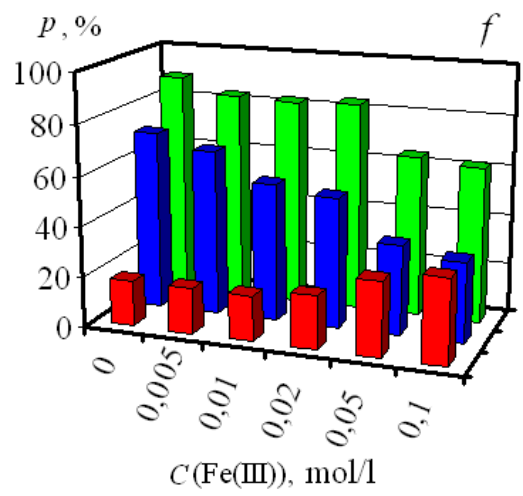

Figure 1. Corrosion parameters of 70C2XA steel in $2 \mathrm{M} \mathrm{H}_{2} \mathrm{SO}_{4}$ : a, d - corrosion rate; b, emetal hydrogenation; c, $\mathrm{f}$ - residual plasticity of steel; $\mathrm{d}, \mathrm{e}, \mathrm{f}-$ in the presence of $4.5 \mathrm{mM}$ IFKhAN-92+0.5 mM KCNS+200 mM urotropine.

Measurements of the plasticity of steel showed more unexpected results. The plasticity of steel increases with the temperature of corrosion tests $(t)$. The observed effect is also a consequence of severe corrosion losses of the metal, which significantly diminish the sample. We assume that when a strip is produced from high strength steel by its mechanical and thermal treatment, strength properties are mainly acquired by the surface layers. The structure of the metal surface layers is susceptible to the penetration of hydrogen into it. Hydrogenation of this part of the metal reduces its plasticity, and subsequent mechanical impact will lead to its destruction. The deep layers of the metal, which are less exposed to mechanical impact during the strip production, have different structures and properties. When the metal is in contact with hot acid and the corrosion rate is high, the surface layer of steel is removed. The remaining part of the metal strip consists of a more plastic material whose mechanical properties are not affected by hydrogenation. As a result, the samples that were exposed in the acid solution at $60^{\circ} \mathrm{C}$ acquire plasticity that is several times higher than that of the metal in the initial state. For a better understanding of this effect and a detailed explanation, deeper studies by special methods are needed, but this issue is outside the objective of this study. It is worth noting that a similar phenomenon was observed at $60^{\circ} \mathrm{C}$ in $2 \mathrm{M} \mathrm{H}_{3} \mathrm{PO}_{4}$ and $2 \mathrm{M} \mathrm{H}_{2} \mathrm{SO}_{4}+\mathrm{H}_{3} \mathrm{PO}_{4}$ 
background solutions. The plasticity of steel correlates with its hydrogenation only at $25^{\circ} \mathrm{C}$ in $2 \mathrm{M} \mathrm{H}_{2} \mathrm{SO}_{4}$ and increases with an increase in the $\mathrm{Fe}(\mathrm{III})$ content in the solution.

Addition of $4.5 \mathrm{mM}$ IFKhAN-92+0.5 mM KSCN+200 mM urotropine to $2 \mathrm{M} \mathrm{H}_{2} \mathrm{SO}_{4}$ $\left(t=25\right.$ to $\left.60^{\circ} \mathrm{C}\right)$ significantly inhibits the corrosion of 70C2XA steel, but this effect disappears in the presence of the Fe(III) salt. At $C_{\mathrm{Fe}(\mathrm{III})}=0.1 \mathrm{M}$, the value of $k$ for steel increased by more than an order of magnitude in comparison with the solution without it. In the cold acid, the inhibitor slows down the hydrogenation of steel, but as $t$ increases, this effect disappears, and at $t=60^{\circ} \mathrm{C}$, hydrogenation of steel becomes higher than in the background solutions. The presence of the Fe(III) salt in the solution decreases the hydrogenation of the metal, the maximum value of which depends on the temperature and varies from 56 to $92 \%$ of the value observed in solutions without $\mathrm{Fe}_{2}\left(\mathrm{SO}_{4}\right)_{3}$. There is no correlation between the strength properties of the metal and its hydrogenation. Only at $t=60^{\circ} \mathrm{C}$, it can be noticed that an increase in the content of Fe(III) reduces hydrogenation and improves the strength properties of steel.

Therefore, addition of $\mathrm{Fe}_{2}\left(\mathrm{SO}_{4}\right)_{3}$ to $2 \mathrm{M} \mathrm{H}_{2} \mathrm{SO}_{4}$ affects both the corrosion of $70 \mathrm{C} 2 \mathrm{XA}$ steel, its hydrogenation, and preservation of plasticity. This effect is more significant in the acid solution that contains the composite inhibitor. The presence of $\mathrm{Fe}_{2}\left(\mathrm{SO}_{4}\right)_{3}$ in an inhibited solution of the acid accelerates the corrosion, especially in hot solutions. Regardless of the presence of the Fe(III) salt in solution, unsatisfactory data on steel hydrogenation are observed at $t \geq 40^{\circ} \mathrm{C}$, and a significant decrease in strength characteristics is noted at all $t$ values. The content of hydrogen in the metal is reduced 2.3-13 fold due to the presence of $\mathrm{Fe}_{2}\left(\mathrm{SO}_{4}\right)_{3}$ in the inhibited solution.

A poor correlation between the strength properties of 70C2XA steel and its hydrogenation should be noted. Probably, a correlation between these parameters is possible at relatively low metal corrosion losses and in the absence of localization of the corrosion process. As follows from the experimental data, in the case of the corrosion process in the background medium, only the data on the strength properties of the metal obtained in a cold solution can be analyzed.

In the inhibited environment, the strength characteristics of steel depend both on the metal hydrogenation and on the possible localization of the corrosion process by the inhibitor. As follows from the above, it is most proper to compare the strength properties of the metal after corrosion in the background and inhibited media exclusively at $25^{\circ} \mathrm{C}$.

Before considering the effect of the Fe(III) salt on the corrosion of 70C2XA steel in the $\mathrm{H}_{2} \mathrm{SO}_{4}+\mathrm{H}_{3} \mathrm{PO}_{4}$ system, it seems essential to carry out studies in $2 \mathrm{M} \mathrm{H}_{3} \mathrm{PO}_{4}$ (see Figure 2). In this acid, the corrosion losses of the metal in the background solution were found to be less, but the accelerating effect of $\mathrm{FePO}_{4}$ on corrosion was higher. The lower corrosion rate of the metal in the hot acid in comparison to that in $\mathrm{H}_{2} \mathrm{SO}_{4}$ leads to a more significant metal hydrogenation. The effect of $\mathrm{FePO}_{4}$ on this process depends on $t$, and the maximum deviation of hydrogenation from the medium without $\mathrm{Fe}$ (III) amounts to $10-85 \%$. A correlation between the strength characteristics of steel and hydrogenation was only found in the cold solution. 


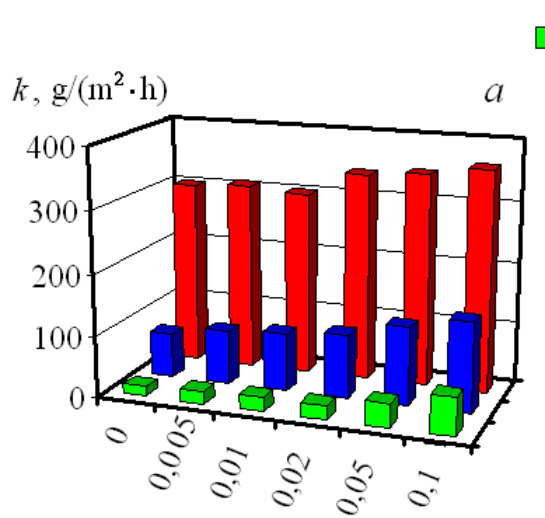

$\mathrm{C}(\mathrm{Fe}(\mathrm{III})), \mathrm{mol} / 1$
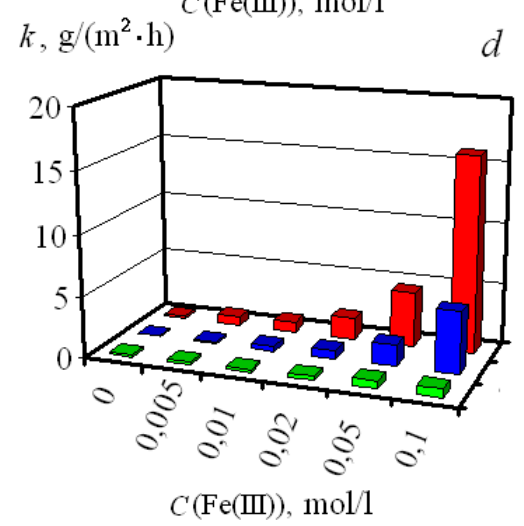

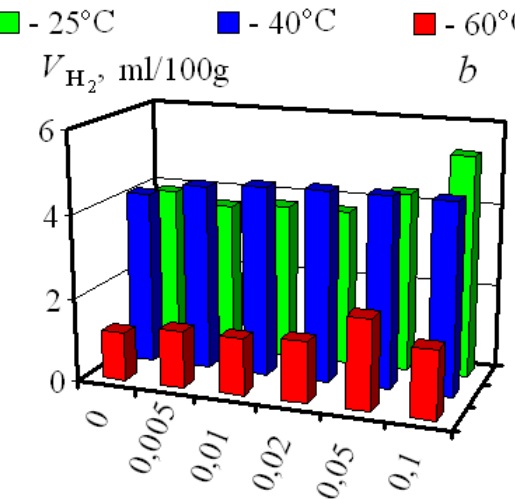

$\mathrm{C}(\mathrm{Fe}(\mathrm{III})), \mathrm{mol} / 1$

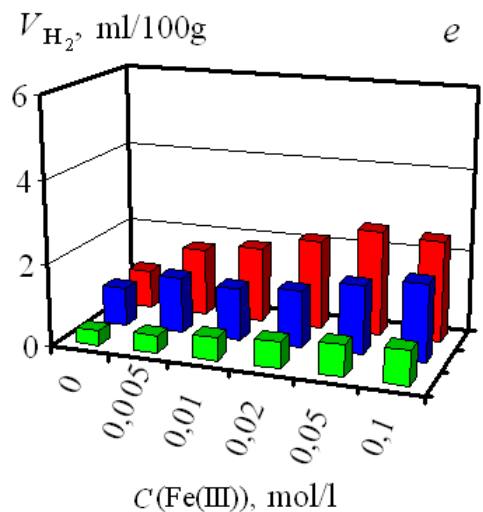

$p, \%$

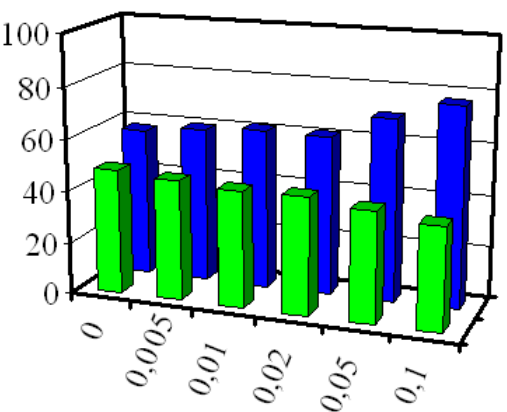

$C(\mathrm{Fe}(\mathrm{III})), \mathrm{mol} / \mathrm{l}$

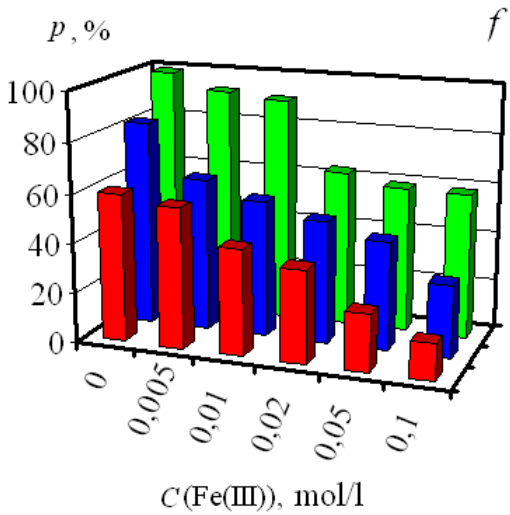

Figure 2. Corrosion parameters of 70C2XA steel in $2.0 \mathrm{M} \mathrm{H}_{3} \mathrm{PO}_{4}$ : $\mathrm{a}$, $\mathrm{d}$ - corrosion rate; b, e metal hydrogenation; c, $\mathrm{f}$ - residual plasticity of steel; $\mathrm{d}, \mathrm{e}, \mathrm{f}-$ in the presence of $4.5 \mathrm{mM}$ IFKhAN-92 + 0.5 mM KCNS + $200 \mathrm{mM}$ urotropine.

The steel is efficiently protected in the inhibited $2 \mathrm{M} \mathrm{H}_{3} \mathrm{PO}_{4}$ solution without $\mathrm{FePO}_{4}$, but the presence of $\mathrm{Fe}$ (III) cations in the solution can significantly accelerate corrosion, especially at $t=60^{\circ} \mathrm{C}$. The maximum values of $k$ observed for steel in the presence of $C_{\mathrm{Fe}(\mathrm{III})}=0.1 \mathrm{M}$ at 25,40 , and $60^{\circ} \mathrm{C}$ amounted to $0.69,5.0$, and $16 \mathrm{~g} /\left(\mathrm{m}^{2} \cdot \mathrm{h}\right)$, which is slightly less than those found in $2 \mathrm{M} \mathrm{H}_{2} \mathrm{SO}_{4}$, where $k$ was $3.0,6.8$, and $19 \mathrm{~g} /\left(\mathrm{m}^{2} \cdot \mathrm{h}\right)$, respectively. The metal hydrogenation in phosphoric media is smaller than in the background solutions. The presence of $\mathrm{FePO}_{4}$ in the inhibited acid enhanced metal hydrogenation (1.9-2.6 fold) and degraded its plasticity. At $t=25^{\circ} \mathrm{C}$, the plasticity of steel was higher in inhibited media than in the background solutions.

The presence of $\mathrm{Fe}(\mathrm{III})$ salts in $2 \mathrm{M} \mathrm{H}_{2} \mathrm{SO}_{4}+\mathrm{H}_{3} \mathrm{PO}_{4}$ accelerates the corrosion, like in the individual acids (Figure 3). The metal is heavily hydrogenated in this environment. At all temperatures $t$, the maximum deviation in hydrogenation from that in the medium without Fe(III) varies within from 12 to $58 \%$. The variation in the plastic properties of steel during etching is similar to that discussed above. Addition of the composite inhibitor significantly inhibits the metal corrosion and hydrogenation, both in the absence and presence of $\mathrm{Fe}(\mathrm{III})$. Under the experimental conditions, the maximum value of $k$ is $1.9 \mathrm{~g} /\left(\mathrm{m}^{2} \cdot \mathrm{h}\right)$. The hydrogenation of steel at $t \leq 40^{\circ} \mathrm{C}$ is no higher than $0.45 \mathrm{~mL} / 100 \mathrm{~g}$. Only 
at $t=60^{\circ} \mathrm{C}$, the maximum value of $V_{\mathrm{H}_{2}}$ attains $2.2 \mathrm{~mL} / 100 \mathrm{~g}$, but in the presence of $0.1 \mathrm{M}$ $\mathrm{Fe}(\mathrm{III})$, it decreases to $1.1 \mathrm{~mL} / 100 \mathrm{~g}$. Fe(III) salts intensify steel hydrogenation 1.7 -fold at $t=25$ to $40^{\circ} \mathrm{C}$ and reduce it 2.0 -fold at $t=60^{\circ} \mathrm{C}$. The presence of $\mathrm{Fe}$ (III) salts impairs the strength properties of steel. The strength properties of the metal are higher in the cold acid in the presence of inhibitor than that without it.
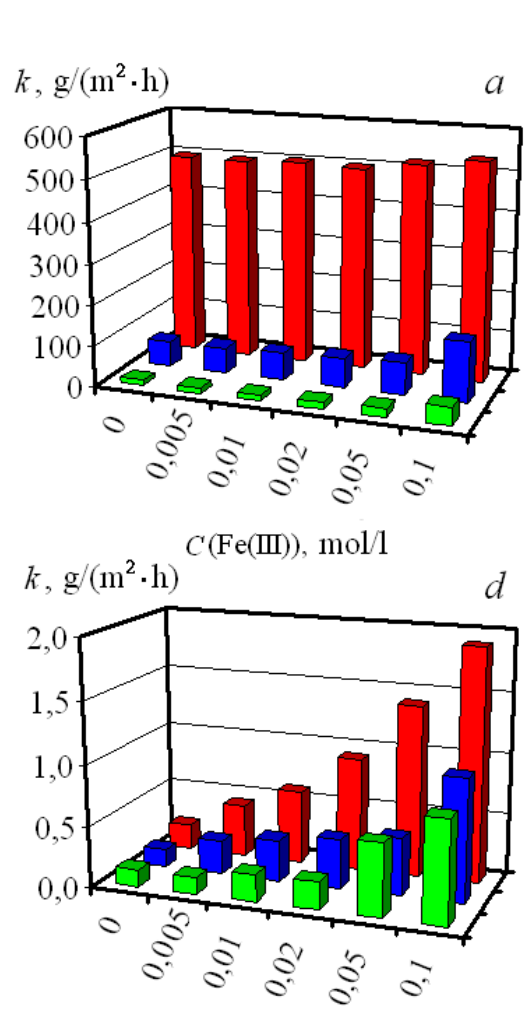

$\mathrm{C}(\mathrm{Fe}$ (III)), $\mathrm{mol} / 1$ $\square-25^{\circ} \mathrm{C} \quad \square-40^{\circ} \mathrm{C}$

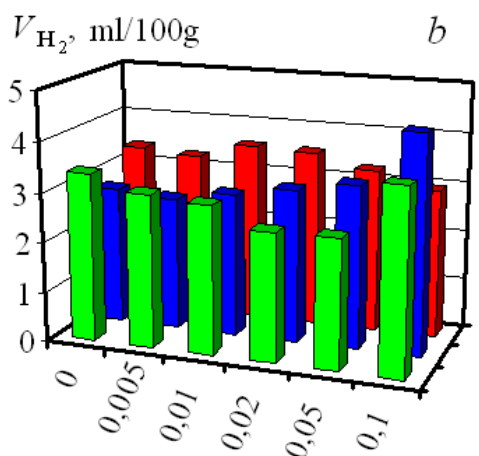

$C(\mathrm{Fe}(\mathrm{III})), \mathrm{mol} / \mathrm{l}$

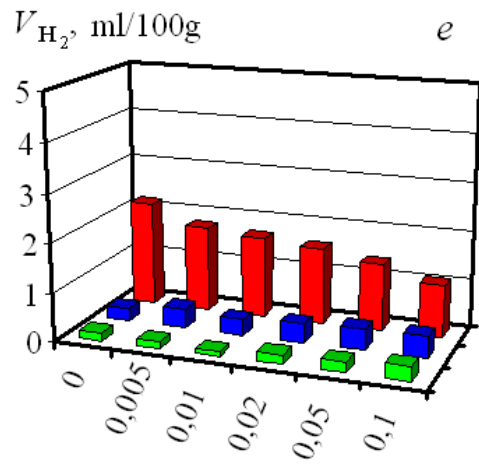

$\mathrm{C}(\mathrm{Fe}$ (III)), $\mathrm{mol} / 1$

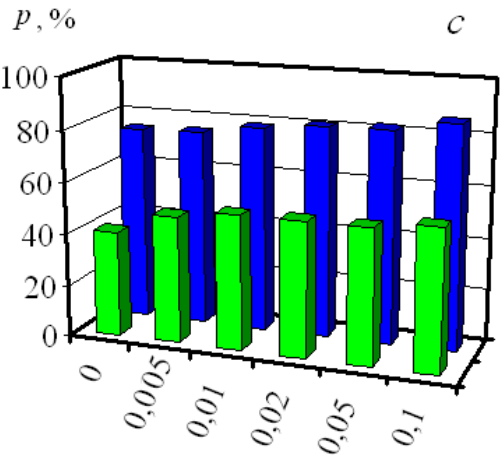

$C(\mathrm{Fe}(\mathrm{III})), \mathrm{mol} / 1$

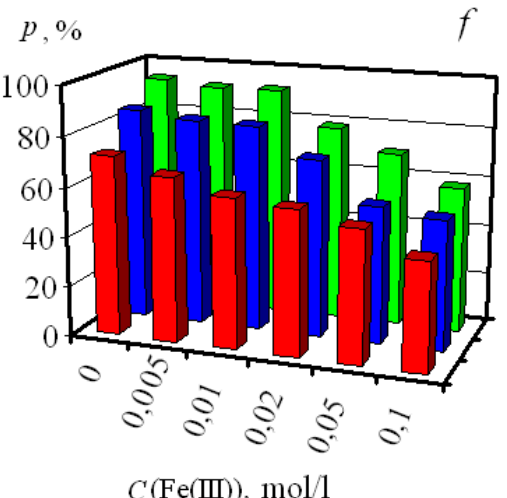

Figure 3. Corrosion parameters of 70C2XA steel in $1 \mathrm{M} \mathrm{H}_{2} \mathrm{SO}_{4}+1 \mathrm{M} \mathrm{H}_{3} \mathrm{PO}_{4}$ : a, $\mathrm{d}$ - corrosion rate; $\mathrm{b}, \mathrm{e}-$ metal hydrogenation; $\mathrm{c}, \mathrm{f}-$ residual plasticity of steel; $\mathrm{d}, \mathrm{e}, \mathrm{f}-\mathrm{in}$ the presence of $4.5 \mathrm{mM}$ IFKhAN-92+0.5 mM KCNS+200 mM urotropine.

Thus, satisfactory data on the protection of 70C2XA steel were obtained for the $\mathrm{H}_{2} \mathrm{SO}_{4}+\mathrm{H}_{3} \mathrm{PO}_{4}$ mixture containing $\mathrm{Fe}(\mathrm{III})$ salts. The highest quality of metal protection is observed at $t=25^{\circ} \mathrm{C}$. This effect is preserved in the mixtures containing $25-75 \% \mathrm{H}_{2} \mathrm{SO}_{4}$ (Figure 4). Under these conditions, the maximum values of $k$ and $V_{\mathrm{H}_{2}}$ amount to $1.1 \mathrm{~g} /\left(\mathrm{m}^{2} \cdot \mathrm{h}\right)$ and $0.29 \mathrm{~mL} / 100 \mathrm{~g}$, respectively, and $p \geq 58 \%$. In the background solutions, $k=13-55 \mathrm{~g} /\left(\mathrm{m}^{2} \cdot \mathrm{h}\right), V_{\mathrm{H}_{2}}=2.2-4.7 \mathrm{~mL} / 100 \mathrm{~g}$, and $p=41-58 \%$. It is necessary to be more critical in considering the results obtained at $t \geq 40^{\circ} \mathrm{C}$. The studies were intentionally conducted for 70C2XA steel, which is prone to hydrogenation, to more clearly illustrate the effect of the inhibitor and Fe(III) salts on the corrosion, hydrogenation, and mechanical properties of steel. In the case of high corrosion inhibition, the total hydrogen content in 
the metal is not high $(2.2 \mathrm{~mL} / 100 \mathrm{~g})$ and this steel retains residual plasticity, which, as a rule, is not typical of it in the case of strong hydrogenation.

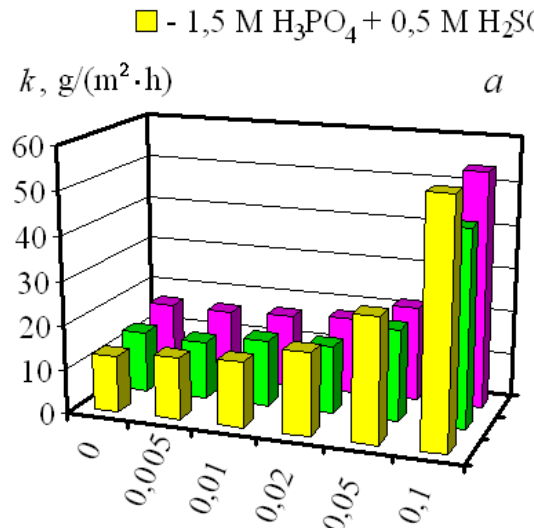

$\mathrm{C}(\mathrm{Fe}(\mathrm{III})), \mathrm{mol} / \mathrm{l}$

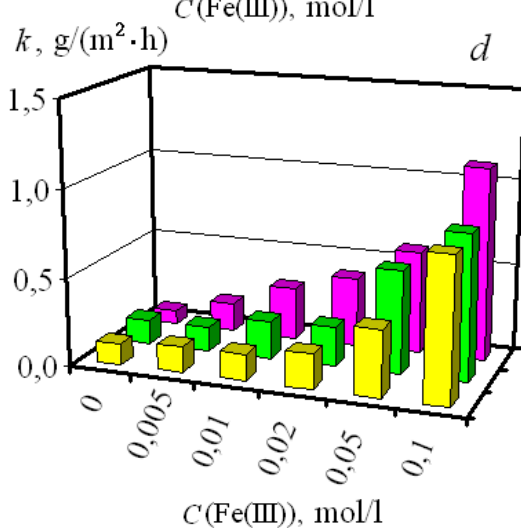

$\square-1,0 \mathrm{M} \mathrm{H}_{3} \mathrm{PO}_{4}+1,0 \mathrm{M} \mathrm{H}_{2} \mathrm{SO}_{4}$

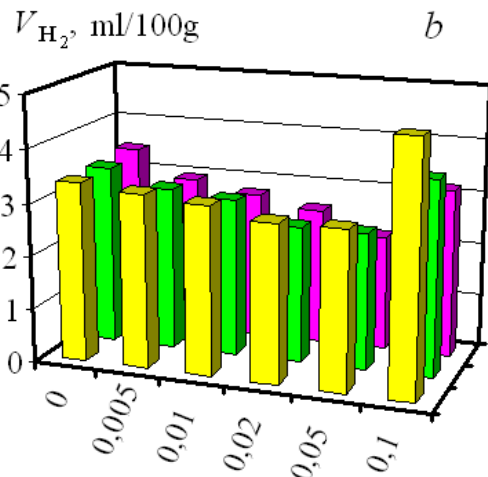

$\mathrm{C}(\mathrm{Fe}(\mathrm{III})), \mathrm{mol} / \mathrm{l}$

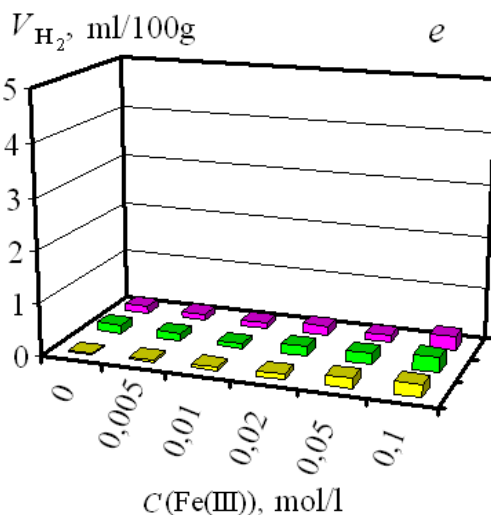

$\square-0,5 \mathrm{M} \mathrm{H}_{3} \mathrm{PO}_{4}+1,5 \mathrm{M} \mathrm{H}_{2} \mathrm{SO}_{4}$

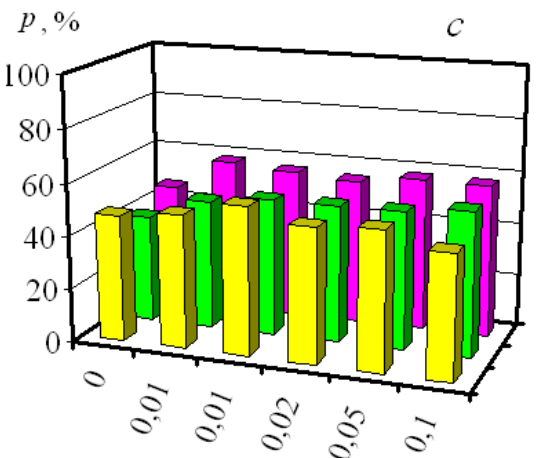

$\mathrm{C}(\mathrm{Fe}(\mathrm{III})), \mathrm{mol} / \mathrm{l}$

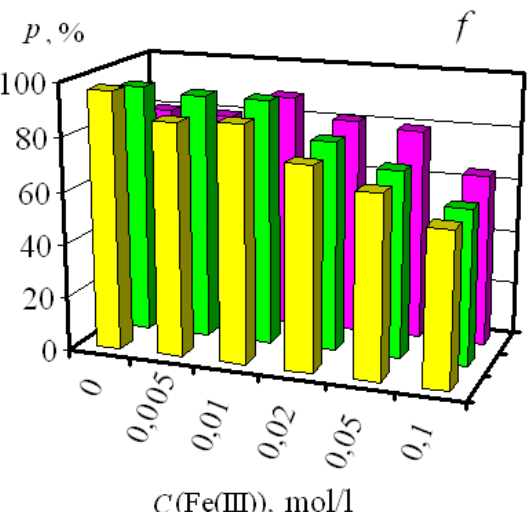

Figure 4. Corrosion parameters of 70C2XA steel in $2 \mathrm{M} \mathrm{H}_{2} \mathrm{SO}_{4}+\mathrm{H}_{3} \mathrm{PO}_{4}\left(25^{\circ} \mathrm{C}\right)$ : a, $\mathrm{d}-$ corrosion rate; $\mathrm{b}, \mathrm{e}-$ metal hydrogenation; $\mathrm{c}, \mathrm{f}$ - residual plasticity of steel; $\mathrm{d}, \mathrm{e}, \mathrm{f}-$ in the presence of $4.5 \mathrm{mM}$ IFKhAN-92+0.5 mM KCNS +200 mM urotropine.

It is crucial to understand whether the ability of the studied inhibitor to prevent the hydrogenation of low-carbon steel persists. At $t=60^{\circ} \mathrm{C}$, the acid solutions containing $\mathrm{Fe}$ (III) can be arranged in the series based on corrosivity toward 08PS steel (see Table 2):

$$
2 \mathrm{M} \mathrm{H}_{2} \mathrm{SO}_{4}>2 \mathrm{M} \mathrm{H}_{2} \mathrm{SO}_{4}+\mathrm{H}_{3} \mathrm{PO}_{4}>2 \mathrm{M} \mathrm{H}_{3} \mathrm{PO}_{4} \text {. }
$$

The Fe(III) salt in the first solution accelerates the corrosion, while its presence in the second and third solutions slows it down. The hydrogenation of steel decreases in the same order, and the values of $V_{\mathrm{H}_{2}}$ are extremely low. Unlike $\mathrm{H}_{2} \mathrm{SO}_{4}$, the inhibitor formulation in $\mathrm{H}_{2} \mathrm{SO}_{4}+\mathrm{H}_{3} \mathrm{PO}_{4}$ and $\mathrm{H}_{3} \mathrm{PO}_{4}$ containing $\mathrm{Fe}$ (III) effectively slows down the corrosion of 08PS steel. Although the hydrogenation of the metal is slightly higher than that in the background solution, it is small and does not exceed $0.40 \mathrm{~mL} / 100 \mathrm{~g}$.

The experimental data on the hydrogenation of low-carbon and high strength steels in acid solutions that we obtained showed that the effect of Fe(III) salts in the medium on this process is not systematic and is largely determined by the steel grade, anionic composition of the solution, its temperature, and the presence of an inhibitor in the environment. The 
character of hydrogenation depends on the content of $\mathrm{Fe}(\mathrm{III})$ cations in the solution. From a practical point of view, it is essential to note that despite the presence of $\mathrm{Fe}$ (III) salts in a solution of the $\mathrm{H}_{2} \mathrm{SO}_{4}+\mathrm{H}_{3} \mathrm{PO}_{4}$ mixture in the entire studied range of their concentrations, the presence of the inhibitor formulation leads to a steady decrease in the metal (high strength steel) hydrogenation or to an extremely small volume of absorbed hydrogen in the metal (low-carbon steel) along with a significant decrease in the metal corrosion losses.

\section{Conclusions}

1. The hydrogenation of low-carbon and high-strength steels in acid solutions containing $\mathrm{Fe}$ (III) salts depends on the chemical composition of steel, anionic composition of the acid solution, concentration of Fe(III) salts, temperature, and the presence of a corrosion inhibitor.

2. The formulation containing $4.5 \mathrm{mM}$ IFKhAN-92+0.5 mM KSCN+200 mM urotropine provides efficient protection against the corrosion and hydrogenation of 70C2XA steel in $2 \mathrm{M} \mathrm{H}_{2} \mathrm{SO}_{4}+\mathrm{H}_{3} \mathrm{PO}_{4}$ in the case of accumulation of $\mathrm{Fe}(\mathrm{III})$ cations in it.

3. Systematic experiments carried out in acid solutions in order to study the hydrogenation of 70C2XA steel specimens and preservation of their plasticity determined as the number of bends of metal specimens showed that no correlation between these parameters was observed in many cases, especially in hot solutions. In some cases, the changes in the plasticity of high-strength steel do not allow us to predict the hydrogenation of metal even indirectly. Satisfactory data on the determination of steel hydrogenation by measuring its plasticity can only be obtained for cold solutions.

4. The corrosion resistance of 08PS steel in acid solutions containing $\mathrm{Fe}(\mathrm{III})\left(t=60^{\circ} \mathrm{C}\right)$ increases in the series: $2 \mathrm{M} \mathrm{H} \mathrm{H}_{2} \mathrm{SO}_{4}<2 \mathrm{M} \mathrm{H} \mathrm{H}_{2} \mathrm{SO}_{4}+\mathrm{H}_{3} \mathrm{PO}_{4}<2 \mathrm{M} \mathrm{H_{3 }} \mathrm{PO}_{4}$. In these environments, steel is resistant to hydrogenation. The $4.5 \mathrm{mM}$ IFKhAN-92+0.5 mM $\mathrm{KSCN}+200 \mathrm{mM}$ urotropine formulation significantly slows down the corrosion of lowcarbon steel in $2 \mathrm{M} \mathrm{H}_{2} \mathrm{SO}_{4}+\mathrm{H}_{3} \mathrm{PO}_{4}$ and $2 \mathrm{M} \mathrm{H}_{3} \mathrm{PO}_{4}$ solutions containing up to $0.1 \mathrm{M}$ $\mathrm{Fe}(\mathrm{III})$. The presence of an inhibitor in the solution causes a very small increase in the hydrogenation of steel compared to the background.

5. In case of a potential danger of accumulation of $\mathrm{Fe}(\mathrm{III})$ salts in inhibited pickling solutions that significantly increase the corrosivity of these solutions for steels, it seems promising to replace them with mixtures of $\mathrm{H}_{2} \mathrm{SO}_{4}$ and $\mathrm{H}_{3} \mathrm{PO}_{4}$ inhibited with IFKhAN-92+KSCN+urotropine (molar ratio of components 9:1:400). Unlike a similar inhibited solution of $\mathrm{H}_{2} \mathrm{SO}_{4}$, the corrosion losses and hydrogenation of low-carbon and high-strength steels are insignificant even in the case of considerable accumulation of $\mathrm{Fe}(\mathrm{III})$ cations (up to $0.1 \mathrm{M}$ ).

\section{Acknowledgments}

This study was carried out under the Fundamental Scientific Research Program of the State Academies of Sciences for 2013-2020: "Development of the fundamental scientific 
foundations of the protective effect of metal corrosion inhibitors in gas and condensed media, nanocomposites, paints and conversion coatings" (State registration number AAAA-A18-118121090043-0).

\section{References}

1. Ya.G. Avdeev, A.V. Panova, T.E. Andreeva and Yu.I. Kuznetsov, Vliyaniye solei $\mathrm{Fe}$ (III) na zashchitu stalei v rastvorakh mineral'nykh kislot ingibitorami korrozii (The effect of $\mathrm{Fe}(\mathrm{III})$ salts on the protection of steels in solutions of mineral acids by corrosion inhibitors), Korroz.: mater., zashch. (Corrosion: materials, protection), 2019, no. 11, 32-40 (in Russian). doi: 10.31044/1813-7016-2019-0-11-32-40

2. Ya.G. Avdeev, O.A. Kireeva, Yu.I. Kuznetsov and I.G. Gorichev, Effect of the anionic composition of acidic solutions containing Fe(III) on the protection of low-carbon steel by a triazole inhibitor, Int. J. Corros. Scale Inhib., 2016, 5, no. 4, 333-346. doi: 10.17675/2305-6894-2016-5-4-4

3. Ya.G. Avdeev, O.A. Kireeva, D.S. Kuznetsov and Yu.I. Kuznetsov, The influence of hexamethylenetetramine on the corrosion inhibition of low carbon steel in mixtures of sulfurous and phosphorus acids containing Fe(III) by IFKhAN-92 and KNCS composition, Prot. Met. Phys. Chem. Surf., 2018, 54, no. 7, 1298-1304. doi: $10.1134 / \mathrm{S} 2070205118070055$

4. Ya.G. Avdeev, Protection of metals in phosphoric acid solutions by corrosion inhibitors. A review, Int. J. Corros. Scale Inhib., 2019, 8, no. 4, 760-798. doi: 10.17675/2305-6894-2019-8-4-1

5. I.V. Nikol'skiy, Navodorozhivaniye stali pri kislotnom travlenii (The hydrogenation of steel at acid etching), ed. S.A. Balezin, 1968, Moscow, Prosvyashchenie, p. 136 (in Russian).

6. S.M. Beloglazov, Navodorozhivanie stali pri elektrokhimicheskikh protsessakh (Hydrogenation of steel in electrochemical processes), 1975, Leningrad, Izdatel'stvo Leningradskogo universiteta, p. 412 (in Russian).

7. A.I. Marshakov, A.A. Rybkina, T.A. Nenasheva and M.A. Maleeva, Vliyanie atomarnogo vodoroda na kinetiku aktivnogo rastvoreniya zheleza. I. Raschet stepeni zapolneniya poverkhnosti zheleza atomami vodoroda i ikh kontsentratsii $v$ poverkhnostnom sloe metalla (The effect of atomic hydrogen on the kinetics of active dissolution of iron. I. Calculation of the degree of filling of iron surface with hydrogen atoms and their concentration in the surface layer of metal), Kondensirovannyye sredy $i$ mezhfaznyye granitsy (Condensed media and interphases), 2012, 14, no. 2, 208-216 (in Russian). 
8. A.I. Marshakov, A.A. Rybkina, T.A. Nenasheva and M.A. Maleeva, Vliyaniye atomarnogo vodoroda na kinetiku aktivnogo rastvoreniya zheleza. II. Metody tsiklicheskogo impul'sa potentsiala i bipolyarnogo elektroda-membrany (The effect of atomic hydrogen on the kinetics of active dissolution of iron. II. Methods of cyclic potential pulse and bipolar membrane electrode), Kondensirovannyye sredy $i$ mezhfaznyye granitsy (Condensed media and interphases), 2012, 14, no. 3, 349-357 (in Russian).

9. A.I. Marshakov, A.A. Rybkina, T.A. Nenasheva and M.A. Maleeva, Vliyaniye atomarnogo vodoroda na kinetiku aktivnogo rastvoreniya zheleza. III. Izucheniye mekhanizma rastvoreniya navodorozhennogo zheleza metodom elektrokhimicheskoi impedansnoi spektroskopii (The effect of atomic hydrogen on the kinetics of active dissolution of iron. III. Study of the mechanism of dissolution of hydrogenated iron by electrochemical impedance spectroscopy), Kondensirovannyye media $i$ mezhfaznyye granitsy (Condensed matter and interphases), 2012, 14, no. 4, 438-447 (in Russian).

10. A.I. Marshakov and T.A. Nenasheva, Kinetika katodnogo vydeleniya i proniknoveniya vodoroda $\mathrm{v}$ zhelezo $\mathrm{v}$ kislom sul'fatnom rastvore $\mathrm{v}$ prisutstvii ingibitorov absorbtsii vodoroda (Kinetics of the cathodic evolution and penetration of hydrogen into iron in an acidic sulfate solution in the presence of hydrogen absorption inhibitors), Korroz.: mater., zashch. (Corrosion: materials, protection), 2004, no. 7, 11-15 (in Russian).

11. A.I. Marshakov, T.A. Nenasheva, A.A. Rybkina and M.A. Maleeva, On inhibiting the iron anodic dissolution in acid sulfate electrolyte by tetrabutylammonium cations, Prot. Met., 2007, 43, no. 1, 77-83. doi: 10.1134/S0033173207010110

12. L.E. Tsygankova and E.S. Kos'yanenko, Vliyaniye katamina AB na katodnoe vydelenie i diffuziyu vodoroda v stal' $v$ sul'fatnykh rastvorakh (The effect of catamine $\mathrm{AB}$ on the cathodic release and diffusion of hydrogen into steel in sulfate solutions), Korroz.: mater., zashch. (Corrosion: materials, protection), 2006, no. 11, 25-32 (in Russian).

13. L.E. Tsygankova, A.S. Protasov and D.B. Balybin, Vliyanie katamina AB na reaktsiyu vydeleniya vodoroda i ego diffuziyu $\mathrm{v}$ stal' $\mathrm{v}$ kislykh khloridnykh sredakh (The effect of catamine $\mathrm{AB}$ on the reaction of hydrogen evolution and its diffusion into steel in acidic chloride environments), Korroz.: mater., zashch. (Corrosion: materials, protection), 2008, no. 7, 25-30 (in Russian).

14. L.E. Tsygankova, A.S. Protasov, D.B. Balybin and N.A. Makol'skaya, Opredeleniye istinnykh konstant skopostey reaktsii vydeleniya vodoroda i ego tverdofaznoi diffuzii v usloviyakh adsorbtsii ingibitora (Determination of the true rate constants of the reaction of hydrogen evolution and its solid-phase diffusion under conditions of inhibitor adsorption), Korroz.: mater., zasch. (Corrosion: materials, protection), 2009, no. 10, 34-38 (in Russian). 
15. Ya.G. Avdeev, L.V. Frolova, D.S. Kuznetsov, M.V. Tyurina and M.A. Chekulaev, Protection of stainless steel in hydrochloric acid solution containing hydrogen sulfide by inhibitors, Int. J. Corros. Scale Inhib., 2016, 5, no. 1, 87-99. doi: 10.17675/23056894-2016-5-1-7

16. Ya.G. Avdeev, L.V. Frolova, D.S. Kuznetsov, M.V. Tyurina and M.A. Chekulaev, Protection of stainless steel in sulfuric acid solution containing hydrogen sulfide by inhibitors, Int. J. Corros. Scale Inhib., 2016, 5, no. 2, 147-158. doi: 10.17675/23056894-2016-5-2-4 